ARTICLES

\title{
THE SECURITY OF MONGOLIA
}

\author{
H. G Schwarz
}

\section{Introduction}

In the last few years, the citizens of Mongolia ${ }^{1}$ have become increasingly preoccupied with national security, particularly as it pertains to their large neighbor to the South, China. As several articles in this journal have already demon sirs $-I$, this concern stretches across a wide field including environ iota, economic, political arid strategic issues. The daily press in Mongolia contains much more of the same. That this concern with national security is not restricted to one or two segments of the population but is shared by the highest leaders of the country is made clear by Mongolia's first official national security doctrine, called the Mongol unseen undressing ayuulguj badly ouzel barbital [Concepts of Mongolia's national security]. ${ }^{2}$ This remarkable document lists no fewer than nine categories of security, most of them implicitly directed toward China.

\section{The Problem}

Many Mongols firmly believe that their country has the unenviable distinction of being saddled with the most difficult security problem on Earth. The facts seem to support this view. Mongolia's geopolitical difficulties have been cited many times, including five that are perhaps the most important: having only two neighbors, no access to the sea, a tiny population in a practically empty land, rich natural resources that are attractive to its neighbors but not so attractive to others to compete for them, and an armed force totally incapable of defending the national territory. These conditions may well be unique - strictly speaking, every nation is endowed, or saddled, with a unique set of circumstances - but is Mongolia's situation really that bad?

\footnotetext{
* Originally presented as and I: cure at the Central Palace of Culture, Ulaanbaatar, on March 7, 1996.

${ }^{1}$ Unless otherwise stated, this article uses the term Mongolia to denote only the Mongolian Republic (Mongol ulus in the Mongolian spelling and Mongol us in the Cyrillic spelling) which between 1924 and 1991 was icon as the Mongolian People's Republic. When applied to event: prior to 1911, the term also include.' Southern Mongolia called Inner Mongolia by the Chinese.

${ }^{2}$ An English translation can be found in The Mongolian Journal of International Affairs 2 (1995), 79-104.
} 
During this century, several countries and territories have shared at least a few problems with Mongolia. Several of them have only one or two neighbors; they range from the minuscule, like Andorra, San Marino, and Liechtenstein in Europe, to the more substantial, like Lesotho and Swaziland in Africa, and the Himalayan states in Asia. ${ }^{3}$ Since only one of these states, Skim, lost its sovereignty when India decided to annex it, this factor - having only one or two neighbors - does not seem to be a universal source of overwhelming weakness. Mongolia's lack of access to the sea, often cited as one of its geopolitical Achilles' heels, is in fact even less problematic than its paucity of neighbors. One needs only to recall the fate of three ocean-hugging states - GAO, Timor, and Kuwait. ${ }^{4}$ It is, however, undeniable that Mongolia's landlocked position subjects its trade to sharply higher costs. When one looks at a third alleged cause of vulnerability, low population density, it is true that Mongolia is virtually an empty country, but this fact does not by itself seem to be serious problem.

What sets Mongolia apart from all other countries is that one of its neighbors maintains a thinly disguised claim to sovereignty over the entire country.

\section{China's Attitude toward Mongolia from 1911 to 1949}

The starting point of any discussion of this subject must be the irrefutable historical fact that no part of Mongolia was ever legally placed under Chinese sovereignty before 1911. The two main parts of Mongolia, North and South, separately submitted themselves to Manchu authority in the seventeenth century. In 1636, the southern khans handed over the seal of the Great Khan to the Manchu ruler Abahai, ${ }^{5}$ and in the 1690 s, the northern khans, while appealing for help against Galdan, the leader of the Western Mongols, submitted themselves to Manchu sovereignty. It should be emphasized that in 1636 , the Chinese state, called Ming, played absolutely no role in the southern Mongols' submission to the Manchus, and that by the 1690s the Ming or any other Chinese government had ceased to exist by virtue of the Manchu conquest of China.

It is, of course, well known that in the course of the long Manchu occupation of China, its government became heavily staffed by Chinese officials and

\footnotetext{
${ }^{3}$ One is tempted to add to this list Mongolia's new near-neighbors to the West, the five postSoviet states of Kazakhstan, Uzbekistan, Tajikistan, and Turkmenia. However, estimates as to their viability are still premature.

${ }^{4}$ That Kuwait regained its independence from Iraq was highly unusual and only succeeded because the American government was determined to retain easy access to Kuwait's oil. In any case, Kuwait's problems are far from over.

${ }^{5}$ Many Mongols consider the events of 1636 not so much a submission of Mongols to Manchus but more a partnership or alliance, albeit an unequal one.
} 
that policies toward other countries incorporated into the Manchu empire, such as Mongolia and Tibet, became influenced by these Chinese officials. None of these developments, however, detracts from the historical fact that all of Mongolia owed its loyalty exclusively to the Manchu court and to no one else. This historical fact was clearly understood by most Mongol leaders. Therefore, as the dissolution of the Manchu court became irreversible toward the end of 1911, leaders in both Northern and Southern Mongolia declared their independence. This independence could not and did not mean independence from China, but merely release from a bond of loyalty to the Manchus.

At this point, geography conspired with geopolitics to create for the first time in Mongolia's long history a split between North and South, a split that has now lasted eighty-five years.

As for the Chinese in general and Chinese governments in particular, since 1911 they have, with rare exceptions noted below, treated Mongolia and the Mongols as part of a greater Chinese fugue (motherland, fatherland, parentland). The very first post-Manchu government of China, in spite of its myriad internal problems, took the time and great expense of insuring that at least the southern Mongols, within reach of Yuan Shikai's armies, will be subjected to direct Chinese rule, an unprecedented event in the history of the two countries' relationship. It took another Chinese government seven years later to try to do the same with the northern Mongols. But there geopolitics stepped in again, this time in the form of the Red Army which forced the Chinese to flee to their own country.

The notion of Mongolia being a part of the Chinese nation was first expressed in the waning years of the Manchu dynasty by the concept of five ethnic groups (Chinese, Manchu, Mongol, Muslim, and Tibetan) comprising China, later to be adopted by Sun Yat-sen and a string of national pretender governments and ultimately, in modified form, by Chiang Kai-shek.

The latter established in his government a so-called Mongolian and Tibetan Committee, staffed by faithful party hacks, whose task it was to deal in a peremptory manner with those two countries. A reading of publications emanating from this organization makes it clear that the committees considered its mandate to include all of Mongolia. All pleas for even the mildest form of autonomy were ignored; wit the predictable result that after 1937, some southern Mongols succumbed to the siren songs of the Japanese imperialists who allowed an ostensibly autonomous Mongolian government to operate on territory they had conquered. 
As for Northern Mongolia, by then called the Mongolian People's Republic, Chiang, like all governments before him, continued to pretend that it was part and parcel of China, in 1945 he seemed to yield to pressures by the USSR and the USA and promised to abide by the results of a plebiscite in November of that year on the question of a "return" to China. When everybody voted against such calamity, Chiang promised to recognize the status quo, only to renege on his promise the following year. What is truly worthy of a place in the theater of the absurd is that today, in 1996, on the subtropical island of Taiwan, textbooks still teach that "Outer Mongolia" a term that had lost its raison deter in 1911, is part of China; and maps printed' there styli she«w China's borders at Kiakhta. Not too long ago, a relief shipment fro«m Taipei to Ulaanbaatar was arranged not by the Foreign Office or the Red Cross, which handled similar shipments to other countries, but by none other than the Mongolian and Tibetan Committee. In 1994 this same committee invited many Mongols studying abroad, including citizens of the Mongolian Republic, to Taiwan for the so-called national day celebrations on October 10. The invitations left no doubt that all Mongols were considered part of the Chinese fugue. One could add many more examples, but I think the point has been made that it is unrealistic to expect kinder treatment from this "alternative" Chinese government. This brings our quick resume to the leaders of China since 1949.

\section{China's Attitude toward Mongolia Since 1949}

To the superficial observer, the present leadership may seem to have made a clean break with the past and to have accepted historical facts dating back to the seventeenth century. Unfortunately, first impressions can be misleading.

There are two major aspects to this question. The more inclusive and hence more important of the two concerns all of Mongolia and its people. The Central Nationalities Institute (recently renamed University) in Beijing is one of the premier vehicles for the implementation of Party policy toward the Mongols. It is also, significantly and perhaps ominously, the direct successor to Chiang's Mongolian and Tibetan Committee. In its veritable torrent of publications since 1951 when it was founded, the institute has reflected the many twists and turns of China's policies, but at least two themes have never changed. One is that there can be no such thing as meaningful autonomy for the four million Mongols under Chinese rule, and the other is the implication, found everywhere in the literature, speeches and conversations, that all Mongols, including the minority two million who live in the present-day Mongolian Republic, are or ought to be subsumed under a mighty and benevolent Chinese fugue. 
The latter point leads us to the second major aspect, namely the official Chinese policy toward China's northern neighbor. Those who wish to find evidence that China accepts the Mongolian Republic's sovereignty can point to full diplomatic relations which, while severely strained during the "cultural revolution", has never been broken. They can also point to the 1962 treaty that formally fixed the border between the two countries. ${ }^{6}$

But there is more to it than meets the eye. As to the 1962 treaty, one is well advised not to read too much into it and instead should remind oneself that the main objective of that treaty, like similar treaties signed at that time with Pakistan, Nepal, and Burma, was to isolate India in world diplomacy. With regard to the matter of diplomatic relations, one should never forget why they were established. Recognition of the sovereignty of the then Mongolian People's Republic became necessary as soon as the policy of "leaning to one side" was adopted in the late forties. It was part of the price paid for Soviet aid. As any Communist dialectician or any reader of Mao Zedong's On Contradiction knows, a policy like "leaning to one side" is a temporary, tactical maneuver, to be abandoned sooner or later.

Meanwhile, below the surface of recognition, there have been countless incidents that strongly suggest how little has actually changed since 1949 . Virtually everybody, young or old, educated or not, still uses the term Way Meng (Outer Mongolia). Besides, on numerous occasions, the Chinese government has allowed the publication of maps identical to those still printed in Taiwan. Its excuse that such maps were published without its knowledge is not worth a rebuttal. To make matters worse, these incidents must be viewed against a backdrop of ethnic antagonism. In spite of an effort, unprecedented in Chinese history, to inculcate a sense of amity among China's various ethnic groups, clashes, some with fatal results, between Mongols and other groups have continued to occur to this day. By far the bloodiest incidents took place during Mao's "cultural revolution" which in Inner Mongolia was marked by a strong anti-Mongolian bias. Estimates of Mongols killed, almost entirely by Chinese, vary widely, from the Beijing government's official figure of 10,000 to some estimates as high as 100,000 . The fiercest attacks were directed against Mongol intellectuals, especially those who had received some education in the Mongolian People's Republic or in the Soviet Union.

\footnotetext{
${ }^{6}$ One can find the latest affirmation of Chinese official recognition in Li Peng's declaration during his brief stopover in Ulaanbaatar on April, 1994.
} 


\section{China's Rationale}

China's attitude rests on its claim, albeit tacit most of the time, that it is the legitimate successor to the Manchu dynasty, and therefore possesses sovereignty over all parts of the former Manchu empire. China's claims to what I have called its three colonies, namely, Southern Mongolia (called by the Chinese "Inner Mongolia"), Eastern Turkestan (called by the. Chinese "Xinjiang"), and Tibet, has always been quite explicit. ${ }^{7}$ The difference in the nature of China's claims can be traced to the fact that its seizure of these three latter territories has never been seriously challenged and, officially at least, all countries accept China's claim to exclusive sovereignty there.

In order to evaluate the validity of this claim, it might be instructive to compare China's situation to three cases in the twentieth century where, like the Manchu dynasty, major empires broke up.

The latest and most obvious case is, of course, the dissolution of the USSR. So far, Russia has made only a partial claim to be the sole successor to the Soviet Union. At the time of breakup, Russia took over the former Soviet diplomatic facilities, laid claim to control over the strategic forces, most importantly nuclear weapons, and volunteered to assume the largest share of Soviet external obligations. Russia has even hinted that the southern borders of the new Central! Asian republics are also Russia's strategic borders, but it has not made any formal claims to sovereignty over the territory of the former USSR. Judging by the negative response by several successor republics to informal Russian attempts to assert any kind of sovereignty, Russia is not likely to press for full successor status any time soon.

The other two potentially relevant cases occurred at the end of the first world war when the Ottoman and Austro-Hungarian empires collapsed. ${ }^{8}$ From a superficial, legalistic point of view, one might subscribe to the usual interpretation that their collapse was entirely due to the fact that they found themselves on the losing side of the war and the victors stripped them of their empires. A closer look will show that, regardless of that war's outcome, these two empires were doomed because of the rise of ethnic and nationalistic sentiments in the Balkans — the war had been triggered by the infamous assassination in Sarajevo — as well as in the Levant.

\footnotetext{
${ }^{7}$ As in virtually all other questions of national territory, the Beijing and Taipei governments have identical claims.

${ }^{8}$ We do not consider here the German empire which, although it too disappeared at the same time, had not included adjacent countries.
} 
As dissimilar as the three cases are, they do share at least two features that set them apart from the case of the Manchu empire. The dominant (but not necessarily the largest or most populous) country in each of the three cases Russia, Austria, and Turkey, respectively - had created the empire, a fact that could bolster restoration attempts, even though Austria and Turkey have not made and are unlikely to make such attempts. China, on the other hand, did not create the Manchu empire but was one of the countries conquered by and incorporated into that empire. The other difference is that the creators of the Soviet, Austro-Hungarian and Ottoman empires came from within, whereas the Manchu empire was created by conquest from the outside.

\section{Mongolia's Perception}

As seen from Ulaanbaatar, China's claim to be the sole successor state to the Manchu empire and, by extension, to have the right to maintain and, in the case of Mongolia, to restore the boundaries of the former empire is shaky at best. Nevertheless, it is acknowledged that certain international events have played into the hands of Chinese governments. Immediately after the fall of the Manchu dynasty in 1912, the leaders of autonomous Mongolia appealed to the Russian government for protection against the kind of invasion that China was then inflicting upon the southern portions of Mongolia. Not only did Russia not help, but in a series of diplomatic moves, most notably the so-called treaty of Kiakhta in 1915, it acknowledged Chinese sovereignty over all of Mongolia. As Mongols painfully recall, neither Great Britain, the leading power of neither the day, nor any other country raised any objections to this cozy arrangement between two neighbors that reminds one rather forcefully of similar deals, such as the German-Soviet pact of 1939 that sealed the fate of Poland. Mongolia was rescued from almost certain Chinese annexation by the timely intervention in 1921 by troops of a new Russian government, ${ }^{9}$ and from then until the demise of the Soviet Union in 1991, the Mongolian People's Republic could consider itself safe from Chinese attacks.

For the next seventy years, the Soviet umbrella shielded Mongolia from further Chinese designs on its territory, but the price for Mongolia's security turned out to be high. Much has been written about the Soviet impact on the Mongolian state, economy, and society, but there is at least one aspect that has

\footnotetext{
${ }^{9}$ The entry of Russian troops into the Mongolian capital, now called Ulaanbaatar, on July 11, 1921, became the most important political national holiday and, despite great changes in the Mongolian-Russian relationship since 1990, is still being celebrated, in Fact for three days.
} 
remained relatively unexplored: the impact of Soviet policies on Mongolian selfperceptions, both within the country and in relation to neighboring countries. It is a subject that deserves much fuller treatment than is appropriate within the framework of this article, but at least we can, indeed we must, say that the current Mongolian Republic is both beneficiary and victim of the European notion of a state and of Stalin's idea of nationality. ${ }^{10}$ This "inheritance" has numerous consequences, of which none is more pertinent to our discussion than the fact that these two foreign importations make Mongolia's current selfperception ever more removed from and incompatible with Chinas views, as described earlier. Unlike China which hints that Mongols in both Northern and Southern Mongolia are one of the present fifty-six "minority nationalities" (shaoshu minzu), the Mongolian Republic Sinks ethnicity to citizenship with the result that it treats all Mongols living beyond its borders as foreigners. ${ }^{11}$

Since the dissolution of the Soviet Union, Russia has become increasingly absorbed in its domestic affairs while simultaneously seeing its military strength sharply diminished. These cataclysmic changes to the north had an immediate, adverse impact on Mongolia, because Russia withdrew not only substantial economic subsidies but also all of its armed forces that had been stationed in Mongolia and that Mongols had come to perceive as a credible deterrent to China. The result of these changes has been a reawakening of almost forgotten fears and an intensive search for ways of safeguarding the security of the Mongolian Republic.

\section{The Outlook}

So far the search has resulted in the aforementioned national security concepts at the theoretical level, and a remarkably fast expansion of contacts with third countries as well as international organizations. Quite clearly, it is the current government's view that the best defense against China lies in relations with as many countries beyond its two neighbors as possible. These relations have been established in diplomacy, economy, culture, education, and other fields and may soon include limited forms of military liaison. ${ }^{12}$ Given the current

\footnotetext{
${ }^{10}$ A good preliminary discussion of the consequences of Soviet ethnic policies among contemporary Mongols is found in Uradyn Erden Bulag, "Dark quadrangle in Central Asia: empires, ethno genesis, scholars and nation-states" Central Asian Survey 13 (1994), 459-478.

${ }^{11}$ The problem is actually much more severe in the sense that these "foreign" Mongols who, we should remind ourselves, form the great majority of all Mongols, are widely perceived as relies, a derogatory term roughly meaning "half-breed" This problem needs to be thoroughly investigated.

${ }^{12}$ See "Fundamentals of the Military Doctrine of Mongolia" elsewhere in this issue.
} 
emphasis on trade in world diplomacy, Mongolia's government has placed great hopes oh economic pressure as protection from China. As Sanzhaagijn Bayar, the deputy director of the Institute for Strategic Studies recently put it, "[China] will be forced to treat ... neighbors in a manner favorable to Western countries. This is rather tangible guarantee of security for Mongolia"13. I wish I could agree with Bayar's view, but unfortunately the facts as I see them argue against it. China is presently much too large and much too strong economically to accede to foreign demands unless these demands happen to coincide with its own policies. One should think that by now the lessons of the economic boycott after the 1989 Tiananmen incident have been learned by everybody. The truth is that if China wanted to, it could occupy the Mongolian Republic at any time at little or no cost to itself.

I fully support Mongolia's current policy of strengthening relations with as many countries as feasible, and it may well be the best that any Mongolian government can do under the country's unfavorable geopolitical circumstances. It is not a guarantee for security, because in the larger context of the global system of nation-states, an inherently unstable and dangerous place, there can be no security guarantee for any state. For the next several years, I see Mongolia's interests best served by a China preoccupied with economic development. ${ }^{14}$ As long as the present economic boom continues; the Chinese leadership is likely to continue its policy of benign neglect toward the Mongolian Republic. This does not mean that if and when China reaches its declared goal of having become a developed nation, far stronger economically and militarily than now, it will engage in aggressive designs on Mongolia. Taking into consideration present evolutionary processes at work on this planet, it is entirely possible that China, and hopefully much of the rest of the world as well, will be far less interested in matters of borders, territory, and other such hallmarks of the nation-state system. If, however, internal events should cut short China's drive toward its goal of a fully developed economy, two scenarios predicted by some China specialists could become reality and spell trouble for Mongolia. One is a strong China, wracked by several internal political problems, trying to ease domestic pres-

\footnotetext{
${ }^{13}$ Sanzhaagrin Bayar "Mongolia's national security challenges" The Asia Foundation's Center- for Asia Pacific Affairs, Report Number 16 (September 1994), [3]. He repeated this line of reasoning in is: article with the same title in The Mongolian Journal of International Affairs 2 (1995), 13.

${ }^{14}$ Some of the particulars are quite different from Mongolia, but it might be instructive to observe China's present attitude toward the islands in the South China Sea. Although China claims them as national territory for their great strategic and economic importance to the country, it has so far not gone beyond verbal: pairing.
} 
sures by occupying the Mongolian Republic. The other scenario is a China unable to solve severe internal problems and thereby causing great hardships to many people in China, especially the Mongols living in Southern Mongolia. Such a tragic situation might then result in a northward flood of migrants that would wreak havoc in the Mongolian Republic.

In sum, Mongolia has done as much as possible in the international arena to safeguard its national integrity, and I see little benefit in excessive speculation on what China might or might not do. Instead, Mongolia's considerable human and materials resources should be channeled toward developing the country as rapidly as possible. 